$1-1-1999$

\title{
X-ray photoelectron spectroscopy investigations of the chemistries of soils
}

\author{
T. L. Barr \\ E. E. Hoppe \\ S. Hardcastle \\ S. Seal \\ University of Central Florida
}

Find similar works at: https://stars.library.ucf.edu/facultybib1990 University of Central Florida Libraries http://library.ucf.edu

This Article; Proceedings Paper is brought to you for free and open access by the Faculty Bibliography at STARS. It has been accepted for inclusion in Faculty Bibliography 1990s by an authorized administrator of STARS. For more information, please contact STARS@ucf.edu.

\section{Recommended Citation}

Barr, T. L.; Hoppe, E. E.; Hardcastle, S.; and Seal, S., "X-ray photoelectron spectroscopy investigations of the chemistries of soils" (1999). Faculty Bibliography 1990s. 2546.

https://stars.library.ucf.edu/facultybib1990/2546

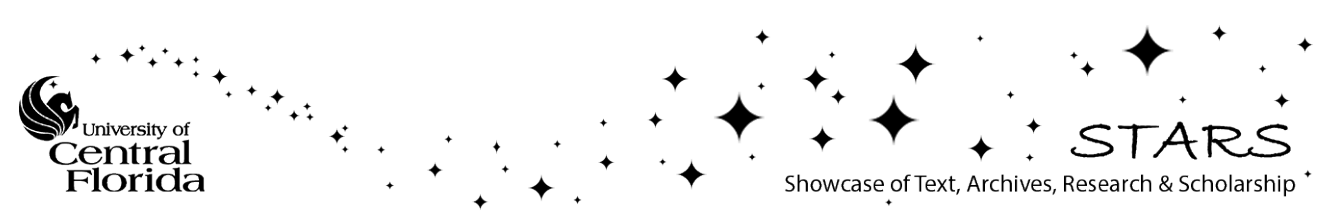




\section{X-ray photoelectron spectroscopy investigations of the chemistries of soils}

T. L. Barr, E. E. Hoppe, S. Hardcastle, and S. Seal

Citation: Journal of Vacuum Science \& Technology A 17, 1079 (1999); doi: 10.1116/1.581778

View online: https://doi.org/10.1116/1.581778

View Table of Contents: https://avs.scitation.org/toc/jva/17/4

Published by the American Vacuum Society

\section{ARTICLES YOU MAY BE INTERESTED IN}

Concerted x-ray photoelectron spectroscopy study of the character of select carbonaceous materials Journal of Vacuum Science \& Technology A 10, 2788 (1992); https://doi.org/10.1116/1.577911

Nature of the use of adventitious carbon as a binding energy standard

Journal of Vacuum Science \& Technology A 13, 1239 (1995); https://doi.org/10.1116/1.579868

Investigations of the surface chemistry of pathogenic silicates

Journal of Vacuum Science \& Technology A 13, 1260 (1995); https://doi.org/10.1116/1.579871

Introduction to Studies of Aluminum and its Compounds by XPS

Surface Science Spectra 5, 1 (1998); https://doi.org/10.1116/1.1247880

Gamma-Alumina $\left(\gamma-\mathrm{Al}_{2} \mathrm{O}_{3}\right)$ by XPS

Surface Science Spectra 5, 18 (1998); https://doi.org/10.1116/1.1247852

Phosphorus Pentoxide $\left(\mathrm{P}_{2} \mathrm{O}_{5}\right)$ by XPS

Surface Science Spectra 9, 159 (2002); https://doi.org/10.1116/11.20030115

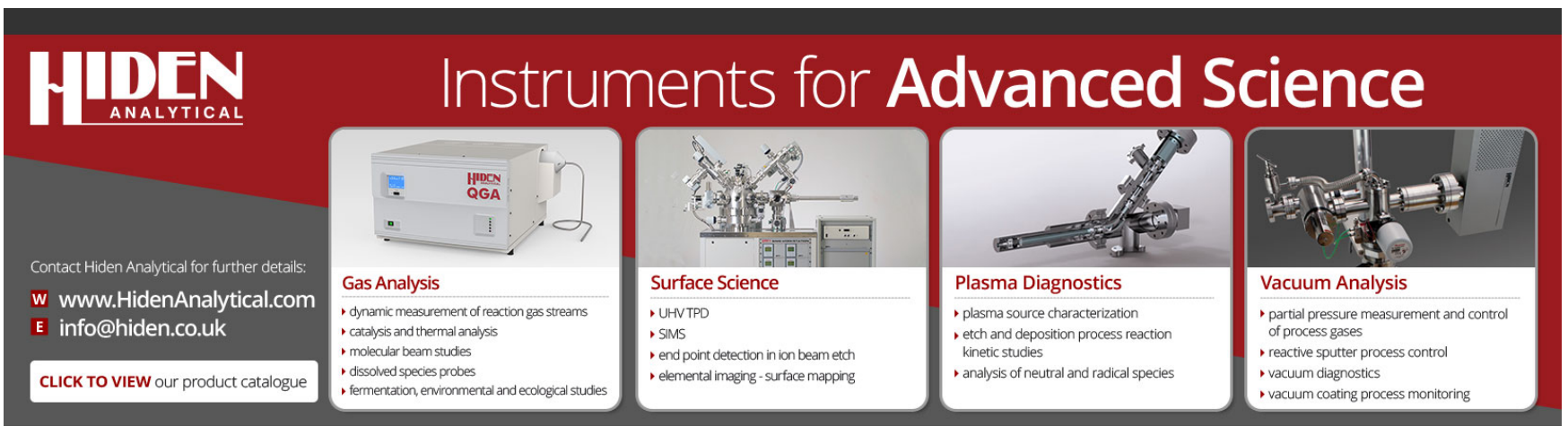




\title{
X-ray photoelectron spectroscopy investigations of the chemistries of soils*
}

\author{
T. L. Barr, E. E. Hoppe, ${ }^{\text {a) }}$ and S. Hardcastle \\ University of Wisconsin-Milwaukee, P.O. Box 784, Milwaukee, Wisconsin 53201 \\ S. Seal \\ University of Central Florida, Mechanical, Materials, and Aerospace Engineering, Orlando, Florida
}

(Received 8 December 1998; accepted 3 May 1999)

\begin{abstract}
The present study continues our x-ray photoelectron spectroscopy (XPS) or electron spectroscopy for chemical analysis investigations of silicate systems, particularly those in contact with biological materials. In the present case, the investigations are extended to a detailed analysis for a wide variety of soil samples extracted from different locations around the world. The samples were selected from relatively pristine sites, pressed into wafers, and were examined without further modification. All of the materials were insulators and therefore analysis required extensive use of the electron flood gun. Careful XPS chemical shift assignments have been achieved for many silicate minerals. These have been exploited in the present study along with the detailed XPS analysis of organofunctional groups rendered by Beamson and Briggs. As a result, a fairly detailed simultaneous nondestructive description is provided of the surface of both the humus and silt components of these soil samples. Substantial variations in the composition are demonstrated and questions are raised about our classifications of fertility. (c) 1999 American Vacuum Society.

[S0734-2101(99)23504-X]
\end{abstract}

\section{INTRODUCTION}

X-ray photoelectron spectroscopy [XPS or electron spectroscopy for chemical analysis (ESCA)] has reached a state of maturity that requires that its users challenge some of its limitations. It is true, for example, that, as the literature points out, the technique often suffers from significant geometric limitations. (One should not forget that XPS is basically a surface tool and if the bulk of materials being examined act differently from their surface then substantial errors can be made in interpretation.) It also should be recognized that XPS results, like many other forms of analysis, are generally dominated by the principal components of any system. Thus, XPS is often insensitive to small amounts of any "dopant" (as, for example, is often the case in microelectronic systems) and further it is often impervious to the details of complex mixtures. Forgotten in the nature of these qualifications is the fact that XPS can provide a wide variety of general answers about complex systems that are often unobtainable by any other form of analysis. Thus, for instance, XPS can be employed to examine the surfaces of a complex (mixed) inorganic system and verify whether a particular chemical species is a major component of that system and also provide evidence as to the integrity of that species. This is possible because every pure species produces its own unique, multifaceted spectra and that singular signature can generally be extracted from that of all the other species that may be present. As a result, XPS is proving to be an ideal tool for principal component surface studies in catalysis, tribology, and coatings. ${ }^{1}$ Recent discoveries by Beamson and

\footnotetext{
*No proof corrections received from author prior to publication.

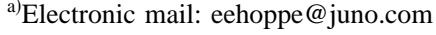

Briggs have provided similar signatures for organic and bio systems. ${ }^{2}$ As a result, XPS is also becoming a useful tool in the study of polymers ${ }^{3}$ and medical ${ }^{4}$ systems. Because of the novelty of the latter efforts, only a few studies have been attempted that have tried simultaneously to examine complex mixed inorganic and organic systems. ${ }^{5}$ In the present study, we partially address this omission by developing XPS to examine a variety of soils (on "dirt" samples) extracted, at random, from around the world. A few related studies form a sparse, but very useful, under pinning for the present information. ${ }^{6,7}$ In so doing we will try to address the following questions:

(1) What are the principal mineral components of the soils?

(2) How do these mineral components compare in type and amount for the different soils?

(3) Is there a repetitive pattern in these differences?

(4) Do we see any evidence of mineral degradation in these soils?

(5) Do we find any identifiable organic units in the soils?

(6) Can we say anything about the origins of these organic units? In particular, are these units indicative of the past (and present) presence of living species?

(7) What evidence is present of the influence of man (including the present analysis team) on these results?

In all of these studies, we must clearly note that the samples were all extracted as loose soils or gravels from just below the exposed surface of the sampling area. Care was employed not to contaminate these samples between extraction and analysis. The only preanalysis conditioning involved air drying and light pressing of particles into a wafer compatible with the ESCA employed in the analyzes. Further 
TABLE I. Soil samples in present study.

\begin{tabular}{ll}
\hline \multicolumn{1}{c}{ Samples } & \multicolumn{1}{c}{ Location } \\
\hline & \\
(1) PSA \\
& Crumbled Bald Eagle Mountain Tailings, \\
(2) Wisconsin (1) & West Branch Susquehanna River, East of Renovo, PA \\
(3) Wisconsin (2) & Shore Sample, Lake Michigan (Wisconsin Side) \\
& $\sim 1 / 2$ mile from Lake Michigan on property at \\
(4) Wisconsin (3) & Newberry Blvd., Milwaukee, WI \\
(5) Arizona (Red) & Forest west of Moorland, WI \\
(High Desert) & Crumbled Mountain Tailing, \\
(6) Arizona (Blonde) & Sedona, Arizona \\
(Low Desert) & 5 miles east of South Mountain, \\
(7) San Diego Inland (1) & Phoenix, Arizona \\
(8) San Diego Shore Line (1) & Sea miles from Pacific Ocean, Chula Vista, CA \\
& \\
(1) Near Krakow, Peach, Coronado Beach, CA & \\
(2) Near Krakow, Poland (2) & \\
\hline \hline
\end{tabular}

${ }^{\text {a} P o l i s h ~ s a m p l e s ~ p r e s e n t l y ~ b e i n g ~ a n a l y z e d . ~}$

considerations of the experimental conditions are presented in the next section.

\section{EXPERIMENT}

\section{A. Analysis system}

All of the XPS results reported in this article were accomplished on a rebuilt Hewlett-Packard (HP) 5950 ESCA System. Critical features included an $\mathrm{Al} K \alpha$ x-ray system with (3) Si crystal monochromator. The vacuum achieved in this system during measurement was always in the low $10^{-9}$ Torr. Most of the samples examined in this study were insulators and therefore produced charging shifts. These shifts and the accompanying peak distortions were removed through proper use of an electron flood gun. The resulting binding energies were further scaled to a preselected value for the $\mathrm{C}(1 s)$ of the hydrocarbon part of any adventitious carbon at $284.6 \mathrm{eV}$. The essential features and justification for this method are described in detail elsewhere. ${ }^{1,8} \mathrm{~A}$ variety of data is obtained, modified and stored on a PC using the S-probe software of the Service, Physics Co. Samples were generally placed into the spectrometer as wafers, lightly pressed from the raw powders.

\section{B. Samples}

All of the samples examined were soils (dirts) that were extracted from the regions indicated in Table I. The same sampling procedure was employed for all of the samples. In this regard, care was employed to make sure that the immediate sampling region was relatively free of moisture and living matter. Samples were taken from a region below the immediate surface, but above any bedrock. This means that, in general, the samples are truly soils. It should be noted that these practices were instituted to try to control the influence of the environment, and particularly human contact. This is not a prevention, of course, because these features have been impacting the properties of soils for centuries, but it should help to assure that many of the features detected are unique to the area sampled.

\section{RESULTS}

\section{A. Precursor studies of select minerals}

A study such as that proposed in the present article would obviously lacks proper interpretation without a detailed XPS examination of the (relatively) pure, singular minerals that should provide the basis ingredients for the present soils. ${ }^{9}$ Fortunately, over the last few years, one of the authors (T.L.B.) and other members of his research group have completed a variety of these basic mineral studies. ${ }^{10-15} \mathrm{~A}$ few of

TABLE II. Quantification of common rock forming minerals.

\begin{tabular}{lllllll}
\hline \hline & $\mathrm{Si} / \mathrm{Al}$ & $\mathrm{Mg}$ & $\mathrm{Fe}$ & $\mathrm{Na}$ & $\mathrm{K}$ & $\mathrm{Ca}$ \\
\hline $\begin{array}{l}\text { Kaolinite } \\
\text { (acid) }\end{array}$ & $1 / 1$ & $\mathrm{VS}$ & $\mathrm{S}$ & $\mathrm{VS}$ & $\mathrm{S}$ & $\mathrm{VS}$ \\
$\begin{array}{l}\text { Illite (base) } \\
\begin{array}{l}\text { Smectite } \\
\text { (base) }\end{array}\end{array}$ & $2 / 1+$ & $\mathrm{M}$ & $\mathrm{M}$ & $\mathrm{VS}$ & $\mathrm{L}$ & $\mathrm{S}$ \\
$\begin{array}{l}\text { Muscovite } \\
\text { (1) rose }\end{array}$ & $1.25 \pm$ & $\mathrm{VS}$ & $\mathrm{VS}$ & $\mathrm{MS}$ & $\mathrm{L}$ & 0 \\
$\begin{array}{l}\text { (acid) (2) } \\
\text { other (acid) }\end{array}$ & & $\mathrm{VS}$ & $\mathrm{M}$ & $\mathrm{S}$ & $\mathrm{L}$ & 0 \\
Margarite & 0.5 & $\mathrm{~S}$ & $\mathrm{~S}$ & $\mathrm{~S}$ & $\mathrm{~S}$ & $\mathrm{~L}$ \\
$\begin{array}{l}\text { Alkali } \\
\text { Feldspar: }\end{array}$ & & & & & & \\
$\begin{array}{l}\text { Orthocolase } \\
\text { Microcline }\end{array}$ & 3.25 & $\mathrm{VS}$ & $\mathrm{S}$ & $\mathrm{ML}$ & $\mathrm{ML}-$ & $\mathrm{MS}$ \\
& 3.25 & $\mathrm{VS}$ & $\mathrm{MS}$ & $\mathrm{M}$ & $\mathrm{L}$ & $\mathrm{MS}$ \\
$\begin{array}{l}\text { Plagioclase } \\
\text { Feldspar: }\end{array}$ & & & & & $\mathrm{L}$ & \\
$\begin{array}{l}\text { Albite } \\
\text { Anorthite }\end{array}$ & 3.25 & $\mathrm{~S}$ & $\mathrm{VS}$ & $\mathrm{L}-$ & $\mathrm{S}$ & $\mathrm{S}-\mathrm{MS}$ \\
& 1.25 & $\mathrm{~S}$ & $\mathrm{VS}$ & $\mathrm{ML}$ & $\mathrm{S}$ & ML- \\
\hline \hline
\end{tabular}


the most pertinent minerals are enumerated in Table II. In addition to these systems, an array of other silicates have been studied with the results demonstrating that XPS examination readily differentiates between different groups of silicates while also often providing separate delineation of individual species. XPS studies ranging from totally unpolymerized ortho-silicates to the three dimensional, framework, variety have been included. Specific reference to the ortho-silicates, pyroxenes, amphiboles, and zeolites is omitted herein, since these species are, almost certainly only minor players in the outer crusted soil samples that are central to the present study. ${ }^{9}$

The major mineral ingredients of soils are known by soil scientists to include primarily select mixtures of the following: silica, the clay minerals, micas, alumino-silicates, and certain oxides and hydroxides, such as Gibbsite, Brucite, and Hemitite, etc. ${ }^{9}$ It should be noted that the minerals listed in Table II are key examples of these general mineral categories.

$\mathrm{SiO}_{2}-\mathrm{As}$ a first and quite simple case, we consider silica. Key to this system are the relatively large binding energy values for both $\mathrm{Si}(2 p) \approx 103.4 \mathrm{eV}$ and $\mathrm{O}(1 s)=532.7 \mathrm{eV}$. Perhaps of even greater importance is the broad characteristically structured valence bands pattern exhibited by pure $\mathrm{SiO}_{2}$, see Figs. 3-10 in Ref. 1. Throughout the present study, we will make use of the breadth and structure of this band, particularly the fact that the trailing edge of the $\mathrm{SiO}_{2}$ band peaks above $14 \mathrm{eV}$, below that of any other silicate. ${ }^{1}$

(Rose) Muscovite-According to Deer et al., ${ }^{9}$ muscovite is a mica with general formula:

$$
\mathrm{K}_{1.8} \mathrm{Na}_{0.2}\left[\mathrm{Al}_{3.5} \mathrm{Fe}_{0.5}\right] \mathrm{Si}_{6.4} \mathrm{Al}_{1.6} \mathrm{O}_{20}(\mathrm{OH})_{4} \text {. }
$$

The Rose Muscovite variety gets its name from its red rose color that is due partly to it structure and in part to its large potassium content. Our samples produced an average $\mathrm{Si} / \mathrm{Al}$ $\sim 1.35$. This value is within the range established in the aforementioned formula. Also of significance in our muscovite results, is the dual facited $\operatorname{Al}(2 p)$ spectrum that demonstrates that two types of aluminum exist in this system. ${ }^{15}$ The binding energies of these two $\mathrm{Al}$ are consistent with our previous detected ion of octahedral $\mathrm{Al}[\mathrm{Al}(2 p) \sim 74.4 \mathrm{eV}]$ and tetrahedral $\mathrm{Al}[\mathrm{Al}(2 p) \sim 73.7 \mathrm{eV}]$. This type of distribution is consistent with the formula of muscovite. ${ }^{9,15}$ Similar observations can be made regarding the $\mathrm{K}$ and $\mathrm{Na}$ distribution. The $\mathrm{Si}(2 p)$ binding energy $(102.5 \mathrm{eV})$ is also consistent with results achieved with other sheet minerals in which the $\mathrm{Si}(2 p)$ binding energy seems to grow with an increase in the [Si/Al]. ${ }^{11}$ One should note, for example, the values for kaolinite and montmorillonite (Table II). ${ }^{11}$ Most of the other sheet silicates known to be major constituents in the earth's crust are not anticipated be of significance in the present study because their octahedral subsheets are centered around $\mathrm{Mg}$, and not Al. These minerals are typified by biotite: ${ }^{9}$

$$
\mathrm{K}_{2} \mathrm{Mg}_{6}\left[\mathrm{Si}_{6} \mathrm{Al}_{2} \mathrm{O}_{20}\right]\left(\mathrm{OH}_{4}\right) \text {. }
$$

This type of composition is atypical of all of the soil samples described in the next section. All these systems, without ex-

\begin{tabular}{|c|c|c|c|}
\hline $\mathrm{C}(1 s)$ & $\begin{array}{l}254.6 \mathrm{eV}^{\mathrm{a}} \\
285.35 \\
268.4\end{array}$ & $\begin{array}{l}\leftarrow 254.15 \\
{[\mathrm{~N}] \sim 0} \\
{[\mathrm{P}] \sim \text { v.s. }}\end{array}$ & \\
\hline & & & $\mathrm{C}=\mathrm{C}-\mathrm{N}$ [v.s. \\
\hline $\mathrm{K}\left(2 p_{3 / 2}\right)$ & $293.35 \mathrm{eV}$ & {$[\mathrm{M}]$} & {$[\mathrm{Na}] \sim \mathrm{S}$} \\
\hline $\mathrm{Ca}\left(2 p_{3 / 2}\right)$ & $347.30 \mathrm{eV}$ & {$[\mathrm{ML}]$} & \\
\hline $\operatorname{Si}(2 p)$ & $102.55 \mathrm{eV}$ & $\begin{array}{l}2.4\{75 \%\}) \\
3.1\{25 \%\})\end{array}$ & \\
\hline $\operatorname{Al}(2 p)$ & $74.25 \mathrm{eV}$ & {$[90 \%]$ Octahedral } & \\
\hline $\mathrm{O}(1 s)$ & $\begin{array}{l}532.0 \mathrm{eV} \\
533.0 \mathrm{eV}\end{array}$ & $\begin{array}{c}{[70 \%] \leftarrow \text { clay-mica }} \\
{[30 \%] \leftarrow \text { feldspar }}\end{array}$ & \\
\hline $\operatorname{Mg}(2 p)$ & $49.95 \mathrm{eV}$ & {$[S]$} & \\
\hline $\mathrm{Fe}(3 p)$ & $56.5 \mathrm{eV}$ & {$[S]$} & \\
\hline $\mathrm{Fe}\left(2 p_{3 / 2}\right)$ & $\begin{array}{l}711.15 \mathrm{eV} \\
712.85 \mathrm{eV}\end{array}$ & & \\
\hline$[\mathrm{Si} / \mathrm{Al}]_{I}=3.1$ & & {$[\mathrm{Si} / \mathrm{Al}]_{\mathrm{C}}=2.1$} & {$[\mathrm{Si} / \mathrm{Mg}]_{\mathrm{C}} \sim 10$} \\
\hline
\end{tabular}

TABLE III. Lake Michigan Shore-Wisconsin.

${ }^{\mathrm{a} S c a l i n g}$ factor.

ception, feature $\mathrm{Al}$ as their second structural cation ( $\mathrm{Si}$ is, of course, the dominant species), i.e., in all cases, $\mathrm{Mg}$ plays only a minor to modest role.

A group of minerals that are known to play a significant role in the composition of the Earth's crust are the framework minerals called the feldspars. ${ }^{9}$ These are the dominant species in the rock formations of mountains. ${ }^{9,16}$ When these rocks are weathered into soils these feldspars tend generally to evolve to micas, clays, and silica. The latter is not a rapid process, nor a complete one, in the sense that all feldspars have not disappeared when soils are present. In fact, those regions that seem to constitute more rocks and pebbles rather than dirt are often regions where substantial feldspars would still be present. Characteristic chemical features of feldspars should be [Si/Al] from 1.25 to 3.25 , and $\mathrm{Si}(2 p)$ binding energies above $102.5 \mathrm{eV}$, but less than $103.25 \mathrm{eV}$. Also feldspars are framework structures in which $\mathrm{Al}$ is substituted for some of the $\mathrm{Si}$ of silica and little or no $\mathrm{Mg}$ or $\mathrm{Fe}$ are involved. As described before each included, tetrahedral Al must also be accompanied by a counter cation, with $\mathrm{Na}^{+}$and $\mathrm{K}^{+}$containing systems, and also $\mathrm{Ca}^{++}$containing forms (with $\mathrm{Si} / \mathrm{Al}=1$ in this latter case) being the major constituents. In the soil samples described below, we will find cases where some feldspars seem to be part of the soil, however, none of the soils would appear to be exclusively feldspars.

\section{B. Precursor to cellular identification}

Some judgements are also possible regarding the presence of organic cellular residues in the soil samples under consideration. For a background to this study, it is suggested that the interested reader should examine Beamson and Briggs, ${ }^{2}$ and our previous study of cell/mineral interactions reported in Surface and Interface Analysis. ${ }^{15}$

\section{ESCA results for soil samples a generality}

The soils examined in this preliminary study are again listed in Tables I and IV. Also included are the points of origin of the samples, some physical features and a few key 
TABLE IV. Relative amounts.

\begin{tabular}{|c|c|c|c|c|c|c|c|c|c|}
\hline $\begin{array}{l}\text { Sample and key } \\
\text { facts }\end{array}$ & $\mathrm{Si} / \mathrm{Al}$ & $\mathrm{Mg}$ & $\mathrm{Fe}$ & $\mathrm{K}$ & $\mathrm{Ca}$ & $\mathrm{N}$ & $\begin{array}{l}\text { Val. } \\
\text { band }^{\text {a }}\end{array}$ & $\operatorname{Si}(2 p)^{\mathrm{a}}$ & $\mathrm{Al}(2 p)$ \\
\hline $\begin{array}{l}\text { Pacific Beach } \\
\text { Coronado Beach, CA }\end{array}$ & 2.15 & MS & MS & ML & ML & $\mathrm{L}$ & Sheet & $\begin{array}{l}\mathrm{F}+ \\
\mathrm{sh}\end{array}$ & $\begin{array}{l}\mathrm{O} \mathrm{T} \\
23\end{array}$ \\
\hline Chula Vista, CA & 2.67 & VS & S & MS & MS & ML & $\begin{array}{l}\mathrm{SiO}_{2} \\
+\mathrm{sh}\end{array}$ & $\begin{array}{l}\mathrm{F}+ \\
\mathrm{sh}\end{array}$ & 34 \\
\hline $\begin{array}{l}\text { Arizona Desert } \\
\text { Phoenix, South } \\
\text { Mountain, AZ }\end{array}$ & 2.6 & ML & M & ML & ML & $S$ & sh & $\begin{array}{l}\mathrm{F}+ \\
\mathrm{sh}\end{array}$ & 43 \\
\hline $\begin{array}{l}\text { Arizona Red High } \\
\text { Desert, Sedona, AZ }\end{array}$ & 2.0 & $S$ & S & ML & ML & VS & $?$ & $\begin{array}{l}\mathrm{F}+ \\
\mathrm{sh}\end{array}$ & 41 \\
\hline $\begin{array}{l}\text { Moreland Divide } \\
\text { Wauwatosa, WI }\end{array}$ & 2.0 & S & S & ML & M & $S$ & $\begin{array}{l}\mathrm{SiO}_{2} \\
+\mathrm{sh}\end{array}$ & $\begin{array}{l}\mathrm{Si}+ \\
\mathrm{F}+ \\
\mathrm{Sh}\end{array}$ & 11 \\
\hline $\begin{array}{l}\text { Newberry Blvd. } \\
\text { Milwaukee, WI }\end{array}$ & 2.3 & MS & MS & M & M & VS & $\begin{array}{l}\mathrm{SiO}_{2} \\
+\mathrm{sh}\end{array}$ & $\begin{array}{l}\mathrm{Si}+ \\
\mathrm{F}+ \\
\mathrm{sh}\end{array}$ & 43 \\
\hline $\begin{array}{l}\text { Lakeshore, Lake } \\
\text { Michigan, WI }\end{array}$ & 2.0 & S & S & M & M & $S$ & $\mathrm{SH}$ & $\mathrm{F}+\mathrm{sh}$ & 61 \\
\hline Pennsylvania (2) & 1.9 & ML & $S$ & $\mathrm{~L}$ & $S$ & MS & sh & $\mathrm{sh}$ & 32 \\
\hline
\end{tabular}

${ }^{\text {a Note: }} \mathrm{F}=$ feldspar, $\mathrm{sh}=$ sheet, $\mathrm{Si}=\mathrm{SiO}_{2}, \mathrm{O}=$ octahedral, $\mathrm{T}=$ tetrahedral.

results. In addition to these data, a much more involved set of results have been collected for all of the soils. A detailed tabulation of the latter for the sample extracted near the Wisconsin shores of Lake Michigan are included in Table III as an example of this detail.

In addition to these results, it should be noted that we have also begun studies of several samples extracted from select soils in Europe. The methods of extraction and transport were similar to those of the previously mentioned samples. A more detailed accounting of the European results will be presented elsewhere, herein we will only briefly mention them for comparative purposes.

The first thing to note about the specifies of these ESCA results, Table IV, is that they are all different from one another. Thus, although all are, as expected, dominated by silicates, they all feature different silicates or, at least, substantially different ratios of similar silicates. This feature is tracked in the [Si/Al] ratio, the $\mathrm{Si}(2 p)$ and $\mathrm{Al}(2 p)$ binding energies, and the counter cations that are found to predominate. All of this suggests that in the case of our different soils we are dealing primarily with materials formed from sedimentary rocks and that the latter arose from some combination of the following:

(1) Different igneous rocks.

(2) Different areas of sedimentation.

(3) Different conditions of weathering.

(4) Vastly different degrees of infusion of residues of organic matter from living organisms (more is said about this later in this article).

The matter of principal concern in these observations is that the ESCA is able to take unaltered soil samples and provide detailed compositional maps. As we will enumerate below, judgements of bonding chemistry and mineral, and even organic, matter identification are also provided.

Despite the obvious dissimilarities found in there soils, perhaps it is even more important to note that in general all samples can be blanketed by the same designation, i.e., mixtures of polymeric alumino-silicate mineral formations. Although this fact is probably not surprising to Earth-bound soil scientists, in our opinion, it should be of particular note to those scientists interested in the potential life-inducing properties of the other terrestrial planets and moons.

\section{SPECIFIC MINERAL ANALYSIS}

\section{A. Background}

It should be apparent that the determination of the specific minerals in the soils in question is still, at best, an educated guess. We are able to apply a number of recently revealed facts and other clues to this problem and at this point these allow us some partially formed suppositions.

First, we should note in that previous studies by soil scientists have broken down the various possible soils into types and based upon some regional maps of the North American Continent, we can suggest the general categories consistent with our sampling regions (see Table V). With this in mind we can also use existing data and suggest some of the mineral types that might be found in the various soils in question. ${ }^{9,17}$

At this point we turn to the ESCA data. All of the features are, of course, mixed and many of these mixed results overlap with one another, but despite this, many singular features stand out. For example, the valence band data do not differentiate between smectites and micas, but they do provide ready evidence of the presence of $\mathrm{SiO}_{2}$ and possibly, certain feldspars. This is indicated by the presence of a high binding energy shoulder at $\sim 14.0-14.5 \mathrm{eV}$. Silica is further indicated by a $\operatorname{Si}(2 p)$ shoulder at $\sim 103.4 \mathrm{eV}$.

The feldspars may be differentiated from $\mathrm{SiO}_{2}$ by the presence of $\mathrm{Al}(2 p)$ at binding energy $>74 \mathrm{eV}$ and a substantial amount of countercation, primarily $\mathrm{K}^{+}, \mathrm{Ca}^{++}$, or $\mathrm{Na}^{+}$. 
TABLE V. Suspected minerals.

\begin{tabular}{|c|c|c|c|}
\hline Sample & $\begin{array}{l}\text { Major } \\
\text { prospect }\end{array}$ & 2nd group & Others \\
\hline Pacific Beach & Feldspar & Smectite + & \\
\hline Coronado Beach, CA & $\begin{array}{l}\text { (Anorthite } \mathrm{Na} \text {, } \\
\text { Ca Orthoclase } \\
\mathrm{K}, \mathrm{Na} \text { ) }\end{array}$ & Illite & \\
\hline Chula Vista, CA & $\begin{array}{l}\text { Feldspar } \\
\text { (Albite) }\end{array}$ & Smectite & $\mathrm{SiO}_{2}$ \\
\hline Arizona (low) desert & Feldspar: & Biotite & $\mathrm{SiO}_{2}$ \\
\hline Phoenix South & Microcline $\mathrm{K}$ & & \\
\hline Mountain, Arizona & Anorthite $\mathrm{Ca}$ & & \\
\hline Arizona Red High & Rose & Margarite & \\
\hline Desert Sedona, AZ & Muscovite & Ca Mica & \\
\hline $\begin{array}{l}\text { Moreland Divide, } \\
\text { Waukesha, WI }\end{array}$ & $\mathrm{SiO}_{2}$ & $\begin{array}{l}\text { Feldspar and } \\
\text { Kaolinite }\end{array}$ & \\
\hline $\begin{array}{l}\text { Newberry Blvd., } \\
\text { Milwaukee, WI }\end{array}$ & Feldspar & $\begin{array}{l}\text { Smectite and } \\
\text { Kaolinite }\end{array}$ & $\mathrm{SiO}_{2}$ \\
\hline $\begin{array}{l}\text { Lakeshore, Lake } \\
\text { Michigan, WI }\end{array}$ & $\begin{array}{l}\text { Muscovite and } \\
\text { Smectite }\end{array}$ & Feldspar & \\
\hline Pennsylvania (2) & $\begin{array}{l}\text { Rose } \\
\text { Muscovite }\end{array}$ & Biotite & \\
\hline
\end{tabular}

Micas also exhibit large amounts of the latter cations, but do not have the high binding energy $\mathrm{Si}(2 p)$ or valence bands. Smectite clays also have $\operatorname{Si}(2 p) \operatorname{Al}(2 p)$ and valence band characteristics similar to some of the key micas, but these clays have less tetrahedral $\mathrm{Al}$ and substantially retarded counter cation populations. Kaolinite clay has a much smaller $\mathrm{Si}(2 p)$, at less prominent V.B. and almost no counter cations.

\section{B. Lake Michigan sample}

With these factors in mind, we consider the ESCA data for our soil samples. As an example of how these facts may be utilized we consider, in detail, the Wisconsin sample extracted near the shores of Lake Michigan. The ESCA details for this sample are presented in Table III. The data demonstrate the multifaceted manner of the present analysis. For example, one should note that based on the reliance of the choice of $284.6 \mathrm{eV}$ as the binding energy for the hydrocarbon part of any adsorbed carbon, we find that peak binding energies are realized for all elemental constituents. The most crucial phase of this part of the present analysis are the values for $\operatorname{Si}(2 p)$ and $\operatorname{Al}(2 p)$. The first value is indicative of the type(s) of silicates present, while the second reflects the relative presence of octahedral versus tetrahedral Al. In the present case, we find a dual $\operatorname{Si}(2 p)$ suggesting in the main a moscovite/smectite mixture, while on the other hand a modest, but significant contribution of either $\mathrm{SiO}_{2}$ or feldspar is indicated. ${ }^{15}$ The $\mathrm{Al}(2 p)$ spectrum suggests a preponderance of octahedral $\mathrm{Al}$, which is consistent with the $\operatorname{Si}(2 p)$ finding. ${ }^{16}$ Other crucial features in Table III are the total and relative amounts of counter cations, with both $\mathrm{Ca}$ and $\mathrm{K}$ plentiful, whereas the $\mathrm{Na}$ content is small. The [Si/Al] ratio for this material is consistent with a mixture of sheet plus framework silicates, i.e., indicated by the value above 2.0.

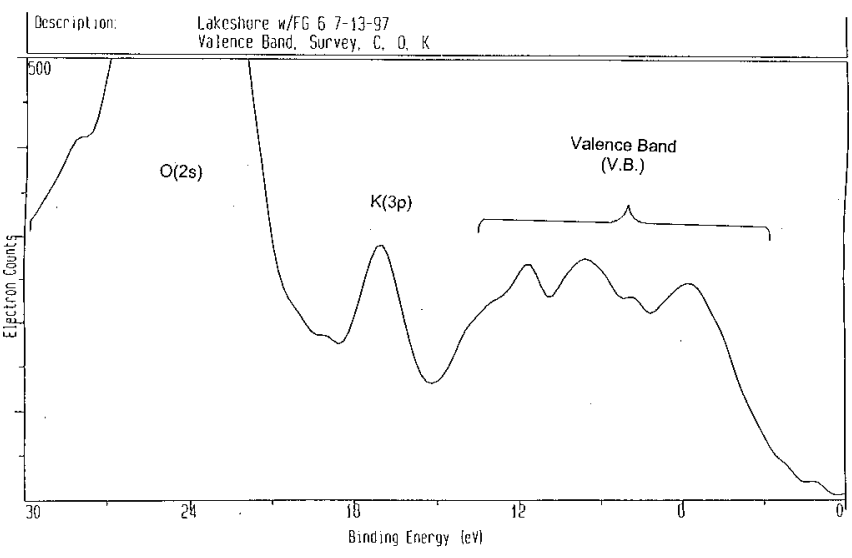

FIG. 1. Valence band region $(0-30 \mathrm{eV})$ for Lake Michigan Shore sample. Note the width of the V.B., plus its several distinct peaks and the "drag" of its leading edge. (Due primarily to lack of singular structure and presence of defect sites.) $\frac{1}{2} E_{g}$ (distance from Fermi edge to leading edge) should be $\sim 4.5 \mathrm{eV}$.

The valence band produced by a the Lake Michigan sample, Fig. 1, is consistent with a substantial presence of sheet silicates, particularly micas, with a modest inclusion of feldspar, the presence of $\mathrm{SiO}_{2}$ is not indicated. All of the other mineral data [e.g., the $\mathrm{O}(1 s)$ binding energy and the counter cation to $\mathrm{Al}$ ratios] support these suppositions. Also, included in those results are the analysis of the $\mathrm{C}(1 s)$ plus the results of the $\mathrm{N}(1 s)$ and $\mathrm{P}(2 p)$ detection. These results have been found to be excellent reflection of the presence of the residues of living cells. ${ }^{15}$ In the present case, the results suggest that this feature is almost entirely absent. As we will amplify below this absence is not reflected in many of the other samples examined.

\section{SUMMARY OF SPECIFIC MINERAL RESULTS}

In addition to the previously described Lake Michigan sample, seven (7) of the soils from around the USA were similarly investigated. Result charts identical to that for Lake Michigan were generated. Some of the key features in these results are expressed in Table IV, along with some of the physical observations. In view of these data, similar suppositions have been reached as to the principal minerals apparently involved in each of these cases, Table V.

In reaching these suppositions, we were constantly aware of their consequences. Thus, for example, we know that at one time the outer crust of Earth was dominated by igneous rock, composed primarily of feldspar and silica, with modest amounts of micas, zeolites, olivines, and pyroxenes. The latter two species were much more prevalent below the surface as they (particularly their iron based forms) had already begun to subduct. The advent of weathering conditions (wind, water, temperature, select pressure, etc.) initiated the gradual destruction of these igneous forms and the granites, granodiorites, and syenites began to break up (the onset of sedimentation). Thus, early sediments exhibited micas and silica, while retaining crumbled versions of feldspars, i.e., a "'presoil.', Subsequent sedimentary evolution induced fur- 
TABLE VI. Possible biocellular presence in soil samples.

\begin{tabular}{llc}
\hline \hline & $\mathrm{C}=\mathrm{O}^{\mathrm{a}}$ & $\mathrm{N}(1 s)^{\mathrm{a}}$ \\
\hline Coronado Beach & $\mathrm{S}$ & $\mathrm{VS}$ \\
Chula Vista & $\mathrm{M}$ & $\mathrm{MS}$ \\
Arizona Desert & $\mathrm{S}$ & $\mathrm{S}$ \\
Arizona Red-Sedona & $\mathrm{S}$ & $\mathrm{S}$ \\
Moreland (in Wisconsin) & $\mathrm{M}$ & $\mathrm{MS}$ \\
Newberry Blvd. (Milwaukee, WI) & $\mathrm{MS}$ & $\mathrm{MS}$ \\
Lake Michigan Shore & $\mathrm{VS}$ & $\sim 0$ \\
Pennsylvania (2) & $\mathrm{S}$ & $\mathrm{VS}$ \\
\hline \hline
\end{tabular}

${ }^{\mathrm{a}} \mathrm{M}=$ Moderate, $\mathrm{S}=$ small, $\mathrm{VS}=$ very small, $0=$ zero.

ther reduction in particle size, further incorporation of water and the introduction of the clay minerals, i.e., true soils. In a sense we may paraphrase this process as the conversion of feldspar to clays, but the total process is a closed loop rather than just a decay curve. Plate subduction and volcanic processes assisted in a process labeled as metamorphosis and this can regenerate feldspars and micas. Consideration of our ESCA results in Table IV and the simplified arguments above leads us to speculate that the samples from California and select versions from the Midwest are indicative of "early soils," where the degree of sedimentation is still somewhat "immature.' The more easternly samples, on the other hand, are more clay-like and further developed. These general points are, however, inconsistent as specific regions often seem to undermine these generalities.

\section{PRELIMINARY STUDY OF SELECT RESIDUES OF LIVING CELLS}

In the course of these analyses and those of another study in which we attempted to grow live cells on asbestosis ${ }^{12,15}$ and other silicate minerals, ${ }^{15,17}$ we have developed several protocols in which we have been able to employ the ESCA to assist in monitoring the presence of surface oriented cellular bodies. The key points involved in all of these analysis is the ESCA detection of particular carbon, nitrogen, and phosphorous peaks. The critical lines are $\mathrm{C}(1 s) \cong 287.7 \mathrm{eV}$ and $\mathrm{N}(1 s) \cong 399.5-8$, due to the presence of the peptide linkage group, $\mathrm{O}=\mathrm{C}-\mathrm{N} .^{2}$ The latter is known to be present in all proteins, DNA, etc. Further, we have looked for the $\mathrm{P}(2 p)$ lines characteristic of organic phosphate linkage units. The latter is somewhat elusive due to the tiny amounts of phosphorous present in these cases, but the former has been a much more readily detected species that has been shown directly to depict the presence of residues of biocellular species.

In the present case, we find that the apparent presence of peptide linkage containing materials is never large, evolving instead between moderate amounts and zero (below our detection limit). Interestingly, as pointed out in Table VI, the presence of this "biocell tracking unit' seems to follow exactly, the course predicted for it. Thus, little or no peptide species are found on the sea shore of California, the Arizona desert, the shores of Lake Michigan and the rock strung plateau mountain walls of Pennsylvania. On the other hand, the field at Chula Vista, California with its grass and trees and the fertile areas of the midwest seem to exhibit significant evidence of the surface (soil) presence of peptide-linkagecontaining species.

It should also be noted that preliminary analysis of some recent results from Poland support all of these suppositions. Thus, an area with what appears to be well developed clay formation exhibits relatively large presences of bodies with $-\mathrm{N}-\mathrm{C}=\mathrm{O}$ units, whereas a feldspar dominated area exhibited little evidence of living cellular forms.

\section{CONCLUSION}

The study described above achieved its primary goal mentioned in the Introduction - that of demonstrating that XPS has matured to the point of permitting meaningful analysis of the surfaces of complex mixed inorganic/organic systems. In this study, chemical information is provided about the most prominent mineral constituents, with sufficient detail to allow us to speculate as to the identity of these complex minerals. In addition, the XPS data permit us to speculate as to the presence of living species on the surfaces the samples in question. For future reference, it is important to note those features not realized to date in this study including:

(1) Although we have occasionally drawn a very loose reference to planetary history, no true semblance of a detailed timeline can be drawn.

(2) In that regard, although some care was employed in sampling we cannot be entirely sure that our analysis represents a registration of the natural evolution of the site in question or some recently imposed alteration.

(3) As pointed out above, many of the minerals suggested have overlapping XPS features, therefore, one should retain a certain skepticism about some of our more detailed speculations

(4) Little, or no evidence is provided about the nature of nonmajor constituents.

(5) It must be remembered that, as pointed out in the Introduction, the studies reported herein are restricted to the surface region of the materials in question. Several other methods of analysis may provide equal, and even, in some cases, more detailed descriptions of complex silicate systems in their bulk regions. This is particularly true of the qualitative and quantitative information provided by energy dispersive $x$ ray and XRF, and the chemical (bonding) descriptions evolved with powder x-ray diffraction. Detailed analysis of the bio-organic "dopants" that are contained in some of the soils can be rendered by mass spectrometry, although the method is perforce a destructive approach. Despite their utility, all of these analysis methods do not reflect the behavior of the materials surface as where, presumably, many key processes would seem to originate. In addition, XPS has been unique in providing simultaneous inorganic and organic chemical analysis of other key silicate/cell mixtures. Similar value may be achieved in subsequent soil studies.

${ }^{1}$ T. L. Barr, Modern ESCA (CRC, Boca Raton, FL, 1994).

${ }^{2} \mathrm{G}$. Beamson and D. Briggs, High Resolution XPS of Organic Polymers (Wiley, Chichester, U.K., 1992). 
${ }^{3}$ B. Ratner, in Concise Encyclopedia of Medical and Dental Materials, edited by D. F. Williams (Pergamon, Oxford, 1989).

${ }^{4}$ S. Seal, S. Krezoski, T. L. Barr, D. H. Petering, J. Klinowski, and P. H. Evans, Proc. R. Soc. London, Ser. B 263, 943 (1996).

${ }^{5}$ S. Seal, S. Krezoski, T. L. Barr, and D. H. Petering, Mater. Res. Soc. Symp. Proc. 414, 183 (1996).

${ }^{6}$ D. L. Cocke, R. K. Vempati, and R. H. Locppert, in Quantitative Methods in Soil Mineralogy, edited by J. G. Amonette and L. W. Zelazny (Soil Science Society of America, Madison, Wisconsin, 1994), pp. 205-235; R. K. Vempati, T. R. Hess, and D. L. Cocke, in Methods of Soil Analysis 3; Chemical Methods, edited by J. M. Bigham (Soil Science Society of America and American Society of Agronomy, Madison, Wisconsin, 1996), pp. 357-375.

${ }^{7}$ See for example, Diem Li, G. M. Bancroft, M. E. Fleet, X. H. Feng, and Y. Pan, Am. Mineral. 80, 432 (1995).

${ }^{8}$ T. L. Barr and M. P. Yin, J. Vac. Sci. Technol. A 10, 2788 (1992); T. L. Barr and S. Seal, ibid. 13, 1234 (1995).

${ }^{9}$ W. A. Deer, R. A. Howie, and J. Zussman, An Introduction to the RockForming Minerals, 2nd ed. (Longman, London, 1992).
${ }^{10}$ T. L. Barr and M. A. Lishka, J. Am. Chem. Soc. 108, 3178 (1986); T. L. Barr, L. M. Chen, M. Mohenian, and M. A. Lishka, ibid. 110, 7962 (1988); T. L. Barr, Zeolites 10, 760 (1990).

${ }^{11}$ T. L. Barr, H. He, and J. Klinowski, Vacuum 46, 1341 (1995); Hitté, T. L. Barr and J. Klinowski, C.-F. Cheng, and P. H. Evans, J. Vac. Sci. Technol. A 13, 1260 (1995).

${ }^{12}$ S. Seal, S. Krezoski, S. E. Hardcastle, T. L. Barr, D. H. Petering, J. Klinowski, C.-F. Cheng, and P. H. Evans, J. Vac. Sci. Technol. A 13, 1260 (1995).

${ }^{13}$ B. Harreras, H. He, T. L. Barr, and J. Klinowski, J. Phys. Chem. 98, 1302 (1994); H. He, T. L. Barr, and J. Klinowski, J. Chem. Phys. 98, 8124 (1994).

${ }^{14}$ S. Seal, S. Krezoski, D. Petering, T. L. Barr, J. Klinowski, and P. H. Evans, J. Vac. Sci. Technol. A 14, 1770 (1996).

${ }^{15}$ T. L. Barr, S. Seal, S. Krezoski, and D. Petering, Surf. Interface Anal. 24, 99 (1996).

${ }^{16}$ T. L. Barr, S. Seal, J. Klinowski, and H. He, J. Chem. Soc., Faraday Trans. 93, 181 (1997).

${ }^{17}$ D. T. Griffen, Silicate Crystal Chemistry (Oxford University Press, Oxford, 1992). 